\title{
Derivatives Disclosures by Major U.S. Banks, 1995
}

Gerald A. Edwards, Jr., and Gregory E. Eller, of the Board's Division of Banking Supervision and Regulation, prepared this article. Terrill Garrison provided research assistance.

The use of derivative contracts has grown rapidly during the 1990s. These off-balance-sheet instruments, whose market value (and cash flow) changes with that of an underlying variable (such as an interest rate, a foreign currency exchange rate, an equity price, or a commodity price), are a powerful tool for companies in managing their exposure to risk. ${ }^{1}$ The increasing importance of derivatives to financial institutions (including banks that are dealers of these instruments), as well as to other enterprises, has heightened the need to understand them better.

Public awareness of these instruments has also grown, a consequence of highly publicized losses by some large businesses and municipalities that had entered into derivative contracts. In a few instances, the losses were blamed on derivatives even though they had in fact resulted from the trading of traditional financial instruments. Nevertheless, these events illustrate the need for firms entering into contracts, shareholders of these firms, policymakers, and the public to understand derivative instruments more fully.

The risks associated with derivatives are no different from the risks that firms have always had to recognize and control (see box "Risks Associated with Derivatives"). All financial contracts carry some degree of risk. Nonderivative contracts, in fact, can be riskier and more complex than derivatives. For example, a junk-rated bond that is tied to a foreign interest rate and is convertible into the issuer's common stock carries credit and market risk that would be difficult to quantify. In contrast, the risks of some derivatives, such as futures contracts, can be easily assessed because prices are observable from trading on exchanges and cash changes hands daily to maintain collateral, mitigating credit risk. Nonetheless, derivatives can be highly complex in their design,

1. See box "Classes of Derivatives" for an explanation of the different types of derivatives and the ways they are used. and their pricing can be opaque, making their risks difficult to understand, measure, and manage.

One approach to increasing public understanding of derivatives has been the implementation of more comprehensive accounting practices and disclosure requirements. In particular, these two tools are helpful in characterizing more accurately the effects of these instruments on firms' financial performance and in explaining those effects through public financial reporting. The benefits of these tools are not limited to derivatives, however. They should also lead to better understanding of how firms manage risks arising from nonderivative financial contracts as well as from other sources. The goals are to demystify derivatives, to facilitate the assessment of firms' derivatives activities by readers of financial statements, and thereby to help improve the allocation of capital by financial markets.

Many groups have been involved in bringing about changes in derivatives accounting and reporting: authorities that set accounting standards, regulators and bank supervisors, and industry associations. These groups have set various regulatory requirements and have made numerous recommendations (see box "Requirements and Recommendations for Public Disclosure"). As a result, the nature of the information publicly disclosed by firms has been evolving in several ways, including the amount and type of information disclosed and the way information is presented.

The published annual reports to shareholders and other public financial reports of banks and other companies play an important role in disseminating information to investors, creditors, and other stakeholders in the enterprises. The information they convey about derivatives has improved significantly in the past few years. A survey of the annual reports of the top ten U.S. banks that deal in derivatives showed that their 1994 reports were substantially more "transparent" than their 1993 reports, with more discussion and analysis of, and more quantitative information about, their use of these instruments. ${ }^{2}$

2. Gerald A. Edwards, Jr., and Gregory E. Eller, "Overview of Derivatives Disclosures by Major U.S. Banks," Federal Reserve Bulletin, vol. 81 (September 1995), pp. 817-31. 


\section{Classes of Derivatives}

Derivatives are contracts that derive their market values by reference to a physical commodity, another contract (such as a debt or equity instrument), or an interest rate or equity index (collectively referred to as "goods"). Some derivative contracts may be settled either by delivery of the contracted-for good or by the payment of cash, while others are settled only in cash. Derivative contracts make reference to a notional amount. The amount is "notional" because it is only an artifice for calculating the amount of cash due periodically. There are two basic classes of derivatives, forwards and options. Both types of instruments are used as a means of transferring, between the parties to the contract, risk associated with possible changes in prices.

\section{Forward Contracts}

A forward contract is a bilateral agreement in which one party, the buyer, is obligated to purchase the contracted-for good and the second party, the seller, is obligated to sell the good to the buyer. At the inception of the forward contract, the quantity and grade of the good, the price to be paid, and the date and location of delivery are fixed. The price to be paid in the future under a new forward contract will be closely related to the good's current market price (its spot price), with adjustments to cover the costs of carrying an inventory of the good during the interim period, such as the costs of storage, insurance, and interest.

Futures. A futures contract is a type of forward that has standard commodity-unit and delivery terms and is traded on an organized exchange. A clearinghouse normally serves as counterparty to both the buyer and the seller. This arrangement reduces credit risk because the parties look to the clearinghouse for performance. Clearinghouses typically reduce their credit risk by requiring that the counterparties put up collateral and by marking to market frequently. Futures are available for agricultural products and other commodities, bonds and other interest-bearing instruments, equity interests, and foreign exchange.

Forward Rate Agreements (FRAs). An FRA is a forward contract between two parties seeking to fix a future interest rate. The parties agree on an interest rate for a specified period associated with a specified notional principal amount (though no commitment to lend or borrow that amount is made). The contract is settled in cash; the payment amount is equal to the product of the notional principal amount and the difference between a spot market rate and the contractual forward rate. If the spot rate on the maturity date is higher than the contracted rate, the seller pays the difference; if the spot rate is lower, the buyer pays the difference.
Swap Contracts. An interest rate swap can be viewed as a contract that bundles a series of forward rate agreements into a single instrument, with one FRA for each swap payment through maturity of the swap contract. In a simple interest rate swap, one party agrees to make fixed cash payments (equivalent to a fixed rate of interest based on a notional principal amount) and the other party agrees to make variable cash payments (equivalent to a floating-rate index such as the London Interbank Offered Rate, LIBOR). Besides interest rates, the structure of exchanging a fixed payment for a floating payment has been applied to such goods as foreign exchange, precious metals, and bulk commodities.

\section{Option Contracts}

An option contract is a unilateral agreement in which one party, the option writer, is obligated to perform under the contract if the option holder exercises his or her option. The option holder pays a fee, or "premium," to the writer for this privilege. The option holder is under no obligation, however, and will exercise the option only when the exercise price is favorable relative to current market prices. If, on the one hand, prices move unfavorably for the option holder, the holder loses only the premium. If, on the other hand, prices move favorably for the option holder, the holder gains (a theoretically unlimited amount) at the expense of the option writer. In an option contract, the exercise (or "strike") price, the delivery date, and the quantity and quality of the commodity are fixed.

Options can be either calls or puts. A call option grants the holder of the contract the right to purchase a good from the option writer, while a put option grants the holder the right to sell the underlying good to the option writer.

Interest rate caps and floors can be viewed as a series of call options packaged into a single financial instrument in which the underlying good is an interest rate index. For example, a borrower arranges to borrow at a variable rate reset quarterly at LIBOR. He also purchases a 6.5 percent rate cap. If LIBOR rises to 9 percent, the borrower pays his creditor 9 percent and receives from the cap writer 2.5 percent ( 9 percent minus the 6.5 percent option exercise price). The borrower has effectively limited his interest expense to a maximum of 6.5 percent plus the premium paid for the interest rate cap.

Under a floor contract, the borrower writes an option in which he agrees to pay the difference between the strike price and the interest rate index specified in the contract. The premium received offsets a portion of the overall interest expense of the obligation; however, the debtor retains exposure to higher interest rates and forgoes the benefit of lower interest rates on his floating-rate obligation. 


\section{Risks Associated with Derivatives}

The risks associated with derivative contracts are no different from those associated with other bank financial instruments. The major categories of risk are described here.

Credit risk is the possibility of loss from the failure of a counterparty to fully carry out its contractual obligations. The types of information about credit risk associated with derivatives that institutions might disclose include the following:

- Gross positive market value-the gross replacement cost of a contract, excluding the effects of any netting arrangements

- Current credit exposure - the fair value on a given date of contracts that are favorable to the holder (that is, are assets)

- Potential credit exposure-a statistical measure of the possible future value of contracts held today if prices or rates move favorably for the holder before the contracts mature

- Credit risk concentrations-indicators of diversification by geographic area or industry group

- Collateral and other credit enhancements that may reduce credit risk

- Counterparty credit quality, nonperforming contracts, and actual credit losses.

Market risk is the possibility that the value of a financial contract (or of a real asset, for that matter) will adversely change before the contract can be liquidated or offset with other positions. The value of these contracts may change because of changes in interest rates (interest rate risk), foreign exchange rates (foreign exchange rate risk), or commodity prices or other indexes.

For some larger institutions, disclosure of information about internal value-at-risk measures and methodology can help financial statement readers understand the institution's exposure to market risk. Using value-at-risk methods involves the assessment of potential losses in portfolio value resulting from adverse movements in market risk factors for a specified statistical confidence level over a defined holding period.

Liquidity risk has two broad types: market liquidity risk and funding risk. Market liquidity risk arises from the possibility that a position cannot be eliminated quickly either by liquidating it or by establishing offsetting positions. Funding risk arises from the possibility that a firm will be unable to meet the cash requirements of its contracts.

Operational risk is the possibility that losses may occur because of inadequate systems and controls, human error, or mismanagement.

Legal risk is the possibility of loss that arises when a contract cannot be enforced because of, for example, poor documentation, insufficient capacity or authority of the counterparty, or uncertain enforceability of the contract in a bankruptcy or insolvency proceeding.
This article follows up on the previous survey by reviewing the 1995 annual reports of the top ten banks that deal in derivatives. Although disclosure requirements did not change during the intervening period, banks nonetheless improved their reporting of derivatives activities in 1995 compared with 1994. In particular, they expanded their discussions of derivatives activities and provided more quantitative information. The vastly greater amount of information presented in the 1995 reports is especially evident when they are compared with the financial statements issued for 1992, in which banks typically disclosed little more than the total value of their trading assets and liabilities, their total trading profits, their overall net credit exposure across all counterparties, and the notional amounts of their derivative contracts. ${ }^{3}$ Regulators and industry groups that have advocated fuller disclosure have clearly had significant influence in

3. The notional amount is the face amount of a contract to which an interest rate, a price, or a rate of exchange is applied to determine the contractual cash payments or receipts. In general, the notional amount is not exchanged and does not reflect the risk of a transaction. improving the overall quality of reporting about derivatives activities.

\section{REVIEW OF 1995 ANNUAL REPORTS}

The institutions whose annual reports were surveyed for this article were the ten U.S. commercial banks having the greatest credit risk exposure from derivatives on December 31, 1995 (taking into account the effects of netting agreements) (table 1). ${ }^{4}$ Nine of the

4. In this article, "bank" refers to a banking organization, comprising bank holding companies, their banking affiliates, and other subsidiaries that are consolidated for purposes of public financial reporting.

Credit risk exposure as of a particular date (current credit exposure) is a measure of the potential loss resulting from a hypothetical default by a counterparty. It is the fair value on the date of measurement of those contracts that are favorable to the bank (that is, those that are assets). If a legally enforceable bilateral netting agreement is in place, credit risk exposure is the net fair value of all contracts subject to the agreement. For example, if a bank has two contracts with a counterparty, one worth $\$ 10$ and the other worth $-\$ 6$, the bank's credit risk exposure is $\$ 10$. If, however, the bank and its counterparty have agreed to net their contracts, the bank's credit risk exposure is $\$ 4$ 
1. Ten U.S. commercial banks with the greatest exposure to credit risk from derivatives on December 31, 1995 Billions of dollars

\begin{tabular}{|c|c|c|}
\hline Institution & $\begin{array}{l}\text { Credit risk } \\
\text { exposure }^{1}\end{array}$ & $\begin{array}{l}\text { Total notional } \\
\text { amount of } \\
\text { derivatives } \\
\text { outstanding }\end{array}$ \\
\hline J.P. Morgan \& Company ...... & 33.6 & 3,403 \\
\hline Chase Manhattan Corporation $^{2}$ & 28.0 & 4,728 \\
\hline Citicorp $\ldots \ldots \ldots \ldots \ldots \ldots \ldots \ldots$ & 19.4 & 2,301 \\
\hline Bankers Trust New York Corporation & 12.1 & 1,742 \\
\hline BankAmerica Corporation ........... & 8.3 & 1,515 \\
\hline First Chicago NBD Corporation & 7.3 & 801 \\
\hline NationsBank Corporation ...... & 3.3 & 1,006 \\
\hline Republic New York Corporation & 3.0 & 268 \\
\hline State Street Boston Corporation & .6 & 58 \\
\hline Bank of New York .............. & .6 & 56 \\
\hline
\end{tabular}

1. Exposure taking into account the effects of legally enforceable bilateral netting agreements.

2. Pro forma combination for Chemical Banking Corporation and Chase Manhattan Corporation.

SourCE. Publicly available regulatory reports filed by bank holding companies with the Federal Reserve.

ten banks were also included in the survey of 1994 annual reports. Two of the 1994 banks, Chemical Banking Corporation and Chase Manhattan Corporation, merged in 1996 and published a combined annual report for year-end 1995. Moving into the group for 1995 was State Street Boston Corporation. ${ }^{5}$

These ten banks dominate the banking industry's share of the derivatives market: Collectively, they accounted for more than 95 percent of the derivatives held or issued by all U.S. banks at year-end 1995 in terms of notional amounts; they accounted for a similar share of the industry's trading portfolios in terms of fair value (table 2). Of the derivatives they held or had issued as of year-end, approximately two-thirds were interest rate contracts and one-third were foreign exchange contracts, with a small amount of equity and commodity exposures. The ten banks also accounted for nearly 90 percent of the profits from trading that were earned by all U.S. banks in 1995.

In their annual reports, banks disclose information about derivative instruments on a consolidated basis (that is, combining all legal entities that make up the enterprise). The information is usually presented in two main sections of the report:

$(\$ 10-\$ 6)$. Note that the current credit exposure of the ten banks on December 31, 1995, was approximately 1 percent of the total notional amount of their outstanding derivative contracts (see table 1).

5. Also included in the tables in this article, to provide a baseline for assessing the extent of change, are data on disclosures in the 1993 annual reports of the top ten banks. The group of banks for that year was essentially the same as in 1994. Continental Bancorp, which was ranked in the top ten in 1993, was acquired by BankAmerica Corporation in 1994. It was replaced in the 1994 survey by Bank of New York, which had been eleventh in 1993 .
- Management's discussion and analysis provides, in narrative form supported by tabular or graphical data, an analysis of the bank's financial condition and performance. As part of its analysis, management typically describes the bank's exposures to risk and its techniques for managing risk. This section is not usually audited by independent accountants.

- The annual financial statement presents statements of financial position, income, changes in stockholders' equity, and cash flow. The financial statement and any accompanying footnotes are typically audited by independent accountants.

This survey considered disclosures in both sections of the annual reports. The analysis was "binary," with coverage judged to be either present or not present, and the decision about whether or not a particular disclosure was present was in many instances subjective. Information on derivatives used for trading purposes was analyzed separately from information on derivatives intended for risk management or other end-user purposes. Because groups that set disclosure standards also recommend that firms report on their trading of nonderivative financial instruments and nonfinancial items (such as precious metals or other physical commodities), we

2. Derivatives positions and trading activity of the top ten banks and all U.S. banks, 1995

Billions of dollars

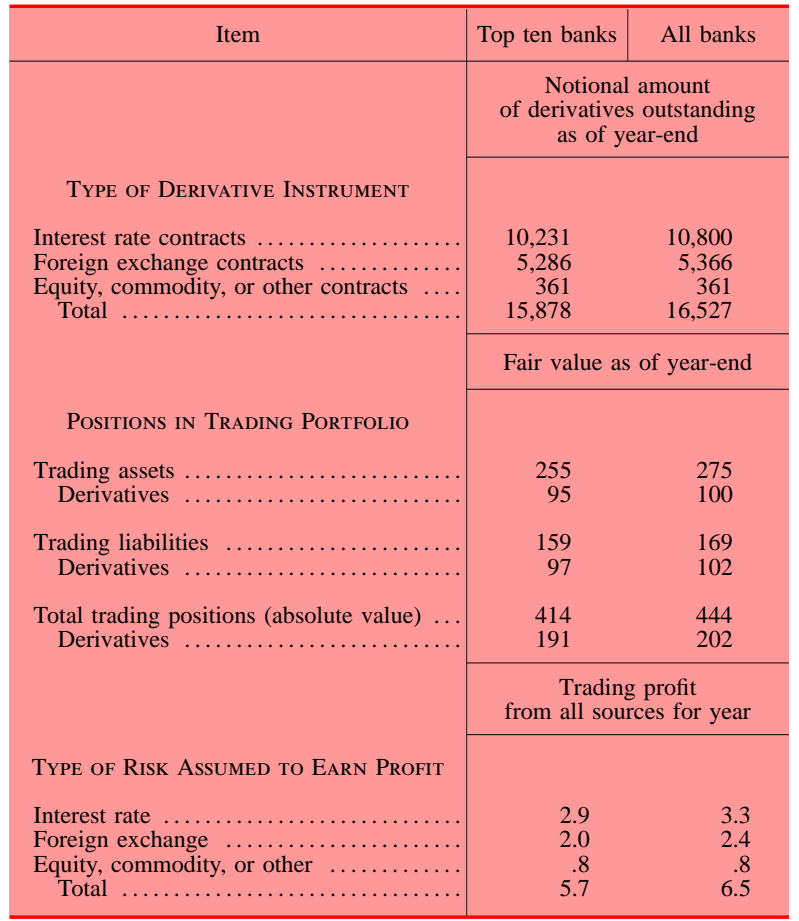

SouRCE. Publicly available regulatory reports filed by bank holding companies with the Federal Reserve. 
also reviewed the reports for disclosures about those instruments. A look at the trading books of the ten banks gives some perspective on the extent of the use of derivatives as a trading vehicle: Derivatives accounted for less than half of the fair value of their trading assets and liabilities on December 31 (table 2). In this article, information for all trading account items is presented to give a more complete picture of trading.

\section{QUALITATIVE INFORMATION}

Managers give qualitative information in the narrative portions of their annual reports in which they identify the risks presented by their business activities and their methods for measuring and controlling those risks. The depth of these narratives on risk has increased substantially over the past few years. The banks' 1993 reports typically had only limited discussions about trading and perfunctory information about derivatives. The 1994 reports had much richer disclosure on these topics. The overriding characteristics of the 1995 annual reports were refinement of methods of disclosure first used in 1994 and further diffusion of these methods among the top ten banks; for example, whereas a 1994 report might have discussed overall value at risk, the 1995 report broke down value at risk into its elements and discussed exposure to different kinds of risk. ${ }^{6}$

\section{Discussion of Specific Risks}

Although nearly all of the banks described credit and market risk in 1994, the 1995 reports contained fuller, more coherent explanations of exposures to those risks (table 3). The 1995 reports as a rule broadened the approaches used in 1994 to frame discussions and analyses of other products (such as bonds) and other lines of business (such as selling foreign currency to customers or trading for the firm's own account as opposed to marketmaking). Also, the reports generally integrated discussions of derivatives into clearer discussions of identical risks inherent in traditional banking books; in contrast, disclosures about market and credit risk in some of the 1994 reports focused solely on derivatives. In 1995, as in earlier years, the

6. Value at risk is a method of measuring risk by estimating potential losses in portfolio value that could result from adverse movements in market prices and other risk factors. The method is based on statistics in which a confidence level and a portfolio holding period are specified.
3. Number of top ten banks discussing their management objectives and the risks of derivatives in their annual reports, 1993-95

\begin{tabular}{|c|c|c|c|}
\hline \multirow{2}{*}{ Type of qualitative disclosure } & \multicolumn{3}{|c|}{ Number of banks disclosing } \\
\hline & 1993 & 1994 & 1995 \\
\hline \multicolumn{4}{|l|}{ 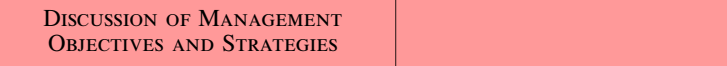 } \\
\hline $\begin{array}{l}\text { For trading activities } \ldots \\
\text { For nontrading activities }\end{array}$ & $\begin{array}{l}4 \\
4\end{array}$ & $\begin{array}{r}9 \\
10\end{array}$ & $\begin{array}{l}10 \\
10\end{array}$ \\
\hline $\begin{array}{l}\text { Discussion of Risks and } \\
\text { ManAGEMENT TeChNiQues }\end{array}$ & & & \\
\hline $\begin{array}{l}\text { Placed in context with balance sheet } \\
\text { risks }\end{array}$ & 7 & 10 & 10 \\
\hline Credit risk & 6 & 9 & 10 \\
\hline Market risk . & 6 & 9 & 10 \\
\hline Liquidity risk $\ldots \ldots \ldots \ldots$ & 4 & 6 & 9 \\
\hline Operating and legal risks & 1 & 3 & 3 \\
\hline
\end{tabular}

depth of discussion was roughly commensurate with the importance of trading profits to the institution's overall income. For example, some banks earned more on deposit account service charges than they did from trading, and the limited level of disclosure about trading may have reflected that priority.

Similarly, banks' discussions of funding liquidity risk at their institutions and their means of controlling it were generally more informative in 1995. Banks summarized their processes for identifying their funding requirements, their procedures for predicting cash needs, and contingency plans for unexpected cash demands. None of the banks, however, discussed the market liquidity of their financial instrument portfolios.

Disclosures of operating and legal risks were somewhat more detailed in 1995, but discussions of management techniques for controlling these risks remained rather shallow. This shallowness may reflect the difficulty of reliably quantifying these risks. However, it is noteworthy that the roots of some of the more notorious trading debacles in recent years can be traced to operating or legal problems; therefore, more discussion of these risks might have been appropriate.

Most of the ten banks described their processes for controlling the risks arising from trading and other business activities by identifying the management group responsible for setting trading policies and by describing the managerial functions responsible for ensuring compliance with those policies. The typical report gave an overview of risk management that sketched the bank's business objectives and its management philosophies (for example, by describing the extent to which its management responsibilities are centralized or diffuse). Most banks also briefly described the information systems and 


\section{Requirements and Recommendations for Public Disclosure}

Although authorities that set accounting standards, regulators, and industry groups have long recognized that there are deficiencies in accounting practices for and disclosure of financial instruments in general, the growing use of derivatives has brought these deficiencies into sharp focus. The Financial Accounting Standards Board (FASB), the organization that sets accounting standards, in 1986 created a task force on financial instruments to address these deficiencies. After some study, the FASB decided that the accounting issues surrounding derivatives would be best addressed by first establishing minimum disclosure requirements and then devising consistent accounting methods. The FASB has so far published three statements of accounting standards (SFAS) affecting disclosures about derivatives and other financial instruments. Financial statements that conform to generally accepted accounting principles necessarily follow these standards.

SFAS 105, Disclosure of Information about Financial Instruments with Off-Balance-Sheet Risk and Financial Instruments with Concentrations of Credit Risk, became effective with 1990 annual reports. It requires the disclosure of the basic contractual terms of certain derivative contracts and discussion of their market and credit risks. It also requires the disclosure of large concentrations in credit risk and, for certain derivative instruments, the disclosure of the loss the firm could incur if counterparties were to default on their obligations.

SFAS 107, Disclosure about Fair Value of Financial Instruments, requires the disclosure of the fair value of derivatives (as well as that of most traditional banking instruments). The standard first applied to 1992 annual reports; it was amended by SFAS 119 for the purpose of making fair value disclosures better organized and more understandable to readers of financial statements.

SFAS 119, Disclosure about Derivative Financial Instruments and Fair Value of Financial Instruments, became effective for 1994 annual reports. It requires firms to differentiate in their disclosures between derivatives used for trading purposes and those used for risk management or other "end-user" purposes.

- Trading activities. For derivatives used for trading, firms must report the fair value of their derivatives positions (both as of year-end and as an annual average) and must report their profits from the trading of derivatives separately; these trading profits may be reported as a total or may be broken down by, for example, line of business (such as sales of foreign currency) or exposure to market risk (such as interest rate or foreign exchange risk).

- End-user activities. Firms must explain their objectives in using derivatives for hedging or other risk-management purposes and must discuss their strategies for achieving those objectives. They must also indicate where in their financial statements end-user derivatives are presented and give certain details about derivatives used to hedge anticipated transactions (such as the amount of gains or losses that were deferred). The fair values of end-user derivatives must be disclosed separately from the fair values of items hedged by the derivatives. Encouraged but not required is the disclosure of quantitative information that managers use as a basis for controlling risk exposure.

\section{Proposed Requirements}

Disclosures in the 1995 annual reports were influenced by requirements formally proposed in December 1995 by the Securities and Exchange Commission (SEC), the agency responsible for administering federal securities laws and for regulating accounting and disclosure by publicly traded companies. The SEC has delegated much of its authority for setting accounting standards for publicly traded companies to the Financial Accounting Standards Board, but it also occasionally issues supplemental guidance. The proposed amendments to current requirements focus on the disclosure of market risk. If adopted, they would become effective for 1996 annual reports.

The SEC proposal requires more detailed disclosure of quantitative and qualitative information about the market risks associated with derivatives. Quantitative information could be disclosed by means of (1) a table showing contract terms and other information, including fair value, expected cash flows, and effective rates and prices; (2) a sensitivity analysis of a hypothetical loss of earnings, fair values, or cash flows resulting from an arbitrary change in current interest rates, foreign exchange rates, or commodity or other prices; or (3) a statement of value at risk expressing the companywide (that is, in trading as well as in other lines of business) loss of fair values, earnings, or cash flows of market-risk-sensitive instruments that might arise from price movements of a given likelihood of occurrence over some time interval, with a separate estimate of value at risk for each type of market risk to which the firm is exposed. Also required would be the disclosure of limitations that might cause the quantitative information about market risk to not fully reflect the overall market risk to the company.

The SEC proposal also requires that companies disclose more detail than currently required by the FASB about their procedures for accounting for derivatives, including information about the accounting methods used, the types of derivatives to which each method was applied, and the criteria for choosing which method to apply.

\section{Recommendations}

In the past two years, several industry groups and regulators, either individually or in association with other agencies, have called for additional disclosure of derivatives activities. These groups have generally stressed the advisory nature of their recommendations, in an effort to encour- 


\section{Requirements and Recommendations for Public Disclosure-Continued}

age firms to develop better ways of informing readers of financial statements and of enhancing market discipline. Their recommendations, though nonbinding, appear to have influenced disclosures in the 1994 and 1995 annual reports.

\section{Euro-currency Standing Committee}

In 1994, a working group of the Euro-currency Standing Committee of the Group of Ten central banks (ECSC) recommended that firms disclose quantitative information about their market and credit risk exposures and their success at managing those risks, to provide a framework for their qualitative discussions. At a minimum, quantitative information about the market risk of the trading portfolio should be disclosed; also desirable is similar disclosure about the consolidated portfolio (that is, about derivatives and financial instruments relating to traditional banking activities as well as to trading). The information should reveal the portfolio's riskiness by indicating the volatility of its market value.

The ECSC also recommended that firms increase the transparency of their disclosures about credit risk. Suggestions include the reporting of current and potential credit exposure and the quantification of the variability of credit exposure over time. Reporting of actual credit losses, arrangements for collateral, and other credit enhancements were suggested to give an indication of the quality of the firm's risk-management practices.

Basle Supervisors Committee and International Organisation of Securities Commissions

In November 1995, the Basle Supervisors Committee (BSC) and the International Organisation of Securities Commis- sions (IOSCO), international associations of national regulators, made several recommendations for the disclosure of more qualitative and quantitative information about trading and derivatives activities and their effect on credit risk and earnings. The groups agreed on using a common set of data provided by regulated enterprises to assess the use of derivatives by these enterprises. The recommendations were issued in connection with a survey of disclosures in the 1994 annual reports of seventy-nine large international banks and securities firms in the Group of Ten (G-10) countries. The 1994 and 1995 annual reports described in this article provided virtually all the data recommended by these groups.

\section{Other Information about Derivatives Available to the Public}

Regulators have long required that banking organizations report notional amounts and fair values of the derivative instruments they hold or have issued. Since 1995, the Federal Reserve and the other federal banking agencies, under the auspices of the Federal Financial Institutions Examination Council (FFIEC), have required that notional amounts and fair values be reported by risk exposure and management objective. Information about trading revenues and the effects of end-user derivatives on accrual-basis income has also been required since 1995, as has the past-due status of derivative contracts and actual credit losses. This information is available to the public. The information required in these regulatory reports appears to have influenced the disclosures made by the larger of the top ten banks in their 1995 annual reports. management tools used to assess the results of their efforts to control risk.

\section{Explanation of the \\ Financial Presentation of Derivatives}

Under generally accepted accounting principles, firms have long been required to describe their accounting policies in general terms. More recently they have had to disclose their means of determining the fair value (sometimes called the fair market value) of many financial instruments they hold or issue. For derivatives, firms must describe not only the way they determine fair value but also the accounting methods under which they recognize income and expense and the legal techniques that underlie their presentation of net credit exposure in financial reports. In meeting these requirements, all ten banks discussed their reasons for using derivatives, identified where in the financial statement information about derivatives was presented, and explained how derivatives were accounted for (that is, by fair value or on an accrual basis; see box "Accounting for Derivative Contracts"). In general, their 1995 descriptions were better organized and more specific than those in earlier reports. The 1995 reports also provided much more detailed and more useful descriptions of the methods and assumptions used in valuing financial instruments that did not have observable market prices.

\section{QUANTITATIVE INFORMATION}

Quantitative information illuminates management's discussion of the firm's financial performance. With respect to derivatives and trading, these data give 


\section{Accounting for Derivative Contracts}

Derivative instruments, like some other financial instruments such as traditional loan commitments, are executory contracts. That is, the two parties to the contract have made mutual promises but have not carried out all the obligations specified in the contract. Under generally accepted accounting principles, an executory contract is reported in a financial statement only after some economic performance (in what may be a series of requirements) has taken placeunder a firm commitment to lend, for example, when funds are drawn. The commitment is "off balance sheet" until some performance occurs. When the cash disbursement is reported as a loan, the financial contract can be said to be "on balance sheet."

In keeping with this accounting principle for executory contracts, the accounting treatment of derivative instruments may reflect only the next required contractual performance during the period covered by the financial statement (such as the accrual of a cash receipt or disbursement characterized as income or expense). Under this procedure, an example of accrual accounting, even though a party to a derivative contract - an interest rate swap, for examplecould be obligated to make a series of cash payments over a number of years if interest rates change adversely, these potential future obligations are not reflected on the balance sheet. Hence, the derivative contract is "off balance sheet," and its potential risks and rewards are obscure. Also, when derivative contracts are used as hedges, losses or gains on them may be deferred to match revenue from loans or interest expenses on deposits or other items being hedged.
Future benefits or obligations associated with off-balancesheet contracts, then, are not well captured in financial statements and therefore lack transparency.

Although executory contracts may not be recognized for accounting purposes, they nonetheless have economic value. For example, an interest rate swap entitling a firm to receive a fixed rate of 8 percent is more valuable than one entitling the firm to receive 7 percent, even though the comparative benefit does not appear on the balance sheet. In some financial reporting situations (such as in reporting trading activities), using economic value is more relevant than using accrual accounting conventions to represent derivatives. The accounting practice of estimating economic value, called marking to market, involves determining the fair value of the contract (by market quote, if available; otherwise through estimation techniques), recording that value on the balance sheet, and recognizing the change in value as a gain or a loss. When derivative contracts are marked to market, their fair value is reflected in accounting statements at a point in time (the balance sheet date) and their volatility is demonstrated through the change in fair value reported in earnings.

Accountants may disagree about which proceduremarking to market or accruing cash flows-more faithfully represents a particular transaction. However, they do agree that more thorough disclosure of the contractual terms of derivative contracts and discussion by management of their hedging programs and the results of those efforts improve the transparency of off-balance-sheet instruments. readers of financial statements an indication of the levels of market and credit risk assumed by the bank and finer detail on the profit the organization earned by taking those risks.

\section{Basic Information on Derivatives Positions}

The top ten banks continued in 1995 to disclose the general contractual terms of their derivative contracts (table 4). All ten reported the notional amounts of such contracts, in all cases distinguishing derivatives used in trading from those intended for other (so called end-user) purposes. Most of the ten provided details on their annual average and year-end trading positions, giving the dollar values of assets and liabilities in their trading portfolios disaggregated among the different classes of derivatives and other items therein. Some types of information published in 1994 appeared less frequently in 1995: gross positive and negative fair values of derivatives positions and, for interest rate contracts held for trading purposes at year-end, detailed schedules of interest rates and maturities.

\section{Disclosures about Traded Derivatives}

Most of the ten banks gave more detail about their trading positions and trading revenues in 1995 than had been done in 1994. This enhancement follows a significant change in the 1994 reports: For that year, generally accepted accounting principles for the first time required that firms separate the fair values of derivative contracts in a gain position (assets) from those in a loss position (liabilities), under much more stringent rules for netting for accounting purposes. ${ }^{7}$ These details were supplemented in 1995 with more information on the types of instruments, both deriva-

7. As a result of this accounting change, the assets and liabilities of one of the ten banks increased \$14 billion. The change had no effect on income, however. 
4. Number of top ten banks disclosing the general terms of their derivative contracts in their annual reports, 1993-95

\begin{tabular}{|c|c|c|c|}
\hline \multirow{2}{*}{ Type of quantitative disclosure } & \multicolumn{3}{|c|}{ Number of banks disclosing } \\
\hline & 1993 & 1994 & 1995 \\
\hline Notional Amounts & & & \\
\hline Dealer (trading account) positions .. & 5 & 9 & 10 \\
\hline $\begin{array}{l}\text { End-user (nontrading account) } \\
\text { positions ............................... } \\
\text { Derivatives traded over the counter }\end{array}$ & 10 & 10 & 10 \\
\hline $\begin{array}{l}\text { separated from those traded } \\
\text { on an exchange } \ldots \ldots \ldots \ldots \ldots\end{array}$ & & 3 & 4 \\
\hline $\begin{array}{l}\text { Maturity schedule } \\
\text { Dealer (trading account) positions }\end{array}$ & 1 & 6 & 2 \\
\hline $\begin{array}{l}\text { End-user (nontrading account) } \\
\quad \text { positions } \ldots \ldots \ldots \ldots \ldots \ldots \ldots\end{array}$ & 7 & 10 & 8 \\
\hline Combined ....................... & 2 & 1 & 3 \\
\hline $\begin{array}{l}\text { Contract rates } \\
\text { Receive or pay rates } \ldots \ldots \ldots \ldots .\end{array}$ & 3 & 10 & 4 \\
\hline Receive or pay notional amounts & 2 & 10 & 4 \\
\hline Fair Value Data & & & \\
\hline $\begin{array}{l}\text { Gross positive fair value } \ldots . \\
\text { Gross negative fair value } \ldots\end{array}$ & $\begin{array}{l}7 \\
0\end{array}$ & $\begin{array}{l}7 \\
6\end{array}$ & $\begin{array}{l}4 \\
4\end{array}$ \\
\hline $\begin{array}{l}\text { Trading account } \\
\text { Trading assets separated from } \\
\text { trading liabilities } \ldots \ldots \ldots \ldots\end{array}$ & 0 & 10 & 10 \\
\hline $\begin{array}{l}\text { Nonderivative instrument detail } \\
\text { End-of-period fair value ..... }\end{array}$ & 0 & 8 & 10 \\
\hline $\begin{array}{l}\text { Average-for-period fair value } \\
\text { Derivative instrument detail }\end{array}$ & 0 & 6 & 7 \\
\hline $\begin{array}{l}\text { Derivative instrument detail } \\
\text { End-of-period fair value ..... }\end{array}$ & 0 & 9 & 10 \\
\hline Average-for-period fair value & 0 & 7 & 7 \\
\hline $\begin{array}{l}\text { End-user positions } \\
\text { Overall fair value } \ldots \ldots \ldots \ldots \ldots\end{array}$ & 9 & 9 & 10 \\
\hline $\begin{array}{l}\text { By related asset or liability being } \\
\text { hedged } \ldots \ldots \ldots \ldots \ldots \ldots \ldots\end{array}$ & 6 & 9 & 6 \\
\hline By type of derivative contract $\ldots$ & 2 & 6 & 4 \\
\hline
\end{tabular}

tive and nonderivative, that made up the year-end fair value (and annual average fair value) of the trading portfolio.

\section{Credit risk}

The state of disclosure about credit risk in 1995 compared with 1994 was mixed (table 5). As in 1994, all ten banks reported their current credit exposure taking into account the effects of bilateral netting agreements. However, additional information about credit risk exposure was generally lacking. Six banks showed how much their gross credit risk exposure on December 31 had been reduced through bilateral netting agreements. Of these six, three also quantified the potential credit exposure of their positions. ${ }^{8}$ None of the banks gave a quantitative measure of the

8. Potential credit exposure is a measure of the probable loss to the bank if the contracts held on a certain date were to become more valuable before they mature because of favorable market price changes and then counterparties were to default. volatility during the year of their credit exposures resulting from their trading activities.

Reflecting a general shortcoming of annual financial statements - one that is not limited to the reporting of derivatives-the ten banks furnished only limited data on the credit quality of the financial instruments they held or their portfolios as a whole. Five banks disaggregated credit exposures for their derivatives portfolios according to whether or not the counterparty was investment grade (as rated by an outside agency or internally), but banks generally did not publish this information for loan or investment portfolios. Disclosure about geographic concentration was less common in 1995 than in 1994. The extent of disclosure of nonperforming contracts was unchanged: Six banks either quantified their actual credit losses and their derivative contracts for which payments were past due or explicitly stated that the amounts were immaterial. In most instances, losses were reported in the context of a discussion of losses incurred from traditional banking activities.

As a supplement to their disclosures of credit risk and capital adequacy, seven banks reported the risk-based-capital credit-equivalent amount of their off-balance-sheet contracts in describing their riskweighted assets and risk-based capital ratios. ${ }^{9}$

9. The risk-based-capital credit-equivalent amount is a measure resulting from the conversion of off-balance-sheet contracts into an equivalent balance sheet asset. Regulatory calculations of risk-basedcapital amounts and ratios are used by supervisors to assess capital adequacy.

5. Number of top ten banks disclosing in their annual reports data on credit risk relating to derivatives they trade, 1993-95

\begin{tabular}{|c|c|c|c|}
\hline \multirow{2}{*}{ Type of quantitative disclosure } & \multicolumn{3}{|c|}{ Number of banks disclosing } \\
\hline & 1993 & 1994 & 1995 \\
\hline Current credit exposure (net) ....... & 10 & 10 & 10 \\
\hline $\begin{array}{l}\text { Reduction of exposure attributed to } \\
\text { bilateral netting agreements }\end{array}$ & 7 & 7 & \\
\hline Potential credit exposure ............ & 1 & 2 & 3 \\
\hline Volatility of credit exposure & 0 & 0 & 0 \\
\hline $\begin{array}{l}\text { Counterparty credit quality } \\
\text { By counterparty type (for } \\
\text { example, bank, other } \\
\text { corporation, government) }\end{array}$ & 4 & 4 & 1 \\
\hline $\begin{array}{l}\text { By internal or external credit } \\
\text { rating of counterparty } \ldots\end{array}$ & 0 & 1 & 5 \\
\hline Concentration & & & \\
\hline $\begin{array}{l}\text { Exposure by geographic area } \\
\text { Exposure by industry group or } \\
\text { government entity }\end{array}$ & 4 & 4 & 1 \\
\hline $\begin{array}{l}\text { Collateral and other credit } \\
\text { enhancements } \ldots . . . .\end{array}$ & 0 & 2 & 1 \\
\hline Actual credit losses ....... & 4 & 6 & 6 \\
\hline Nonperforming contracts $\ldots \ldots \ldots$. & 1 & 6 & 6 \\
\hline $\begin{array}{l}\text { Risk-based-capital credit equivalent } \\
\text { for derivatives } \ldots \ldots \ldots \ldots \ldots \ldots\end{array}$ & 4 & 7 & 7 \\
\hline
\end{tabular}




\section{Market risk}

Most of the ten banks reported details of their measurements of market risk in their 1995 annual reports. Seven reported using value at risk as a means of assessing market risk and gave daily, monthly, or quarterly data. These seven gave varying amounts of detail on the assumed holding period, the high, low, and average value at risk, and portfolio performance versus management's intended limits on losses that could result from market risk exposure (table 6). One bank gave portfolio performance figures without giving details of management's limits on losses. Four reported both management's limits and actual trading profits and losses. The disclosure of numerical details on value at risk was a significant innovation in the 1994 reports and became more widespread in the 1995 reports. Indeed, inclusion of these details is the single most remarkable development in annual report disclosures over the past two years. In their 1993 reports, several institutions indicated that they relied on a value-at-risk method but did not disclose value-at-risk data, and in their 1992 reports they were largely silent about how they managed market risk and gave little or no measure of their market risk exposure.

Several banks included in their 1995 reports additional data on value at risk that reflected a recent proposal by the Securities and Exchange Commission regarding market risk disclosures (see box

6. Number of top ten banks disclosing in their annual reports data on the management of market risk relating to derivatives, 1993-95

\begin{tabular}{|c|c|c|c|}
\hline \multirow{2}{*}{ Type of quantitative disclosure } & \multicolumn{3}{|c|}{ Number of banks disclosing } \\
\hline & 1993 & 1994 & 1995 \\
\hline \multicolumn{4}{|l|}{ Trading Activities } \\
\hline $\begin{array}{l}\text { Value-at-risk information } \\
\text { High and low value at risk for the }\end{array}$ & & & \\
\hline & 0 & 5 & 6 \\
\hline Average daily value at risk $\ldots \ldots$ & 0 & 7 & 5 \\
\hline $\begin{array}{l}\text { Daily change in value of portfolio } \\
\text { Average daily change in value }\end{array}$ & 0 & 4 & 7 \\
\hline of portfolio $\ldots \ldots \ldots \ldots \ldots$ & 0 & 3 & 4 \\
\hline $\begin{array}{l}\text { Frequency of changes in } \\
\text { portfolio value exceeding } \\
\text { value-at-risk limit }\end{array}$ & 0 & 4 & 5 \\
\hline $\begin{array}{l}\text { Confidence interval used in } \\
\text { value-at-risk analysis }\end{array}$ & 0 & 6 & 7 \\
\hline Aggregation across risk factors & 0 & 0 & 4 \\
\hline END-User Activities & & & \\
\hline Effect of derivatives on duration $1 \ldots$ & 1 & 2 & 0 \\
\hline $\begin{array}{l}\text { Effect of derivatives on gap positions } \\
\text { Scenario analysis-Impact of rate }\end{array}$ & 8 & 8 & 8 \\
\hline $\begin{array}{l}\text { Scenario analysis - Impact of rate } \\
\text { shock } \ldots \ldots \ldots \ldots \ldots \ldots \ldots \ldots \ldots \ldots\end{array}$ & 3 & 5 & 6 \\
\hline $\begin{array}{l}\text { Value at risk for nontrading } \\
\text { portfolio } \ldots \ldots \ldots \ldots \ldots \ldots\end{array}$ & 0 & 3 & 1 \\
\hline
\end{tabular}

1. Duration is a method of measuring interest sensitivity that is based on financial instrument cash flows weighted by the time to receipt or payment.
"Requirements and Recommendations"). These banks not only described the market risks of their trading portfolios in terms of value at risk but also published data on their exposure to specific kinds of market risk (for example, interest rate and foreign exchange) as well as a measure of how these risks interacted or correlated to reduce overall market exposure through diversification.

The larger dealers among the ten banks wove these quantitative details into their discussions of riskmanagement policies, giving some flavor of the dynamics of their risk-taking during the year by disclosing their actual trading portfolio results relative to their risk measurements and their risk-control objectives. Several banks used graphics to more fully convey information about their trading portfolios in general, about daily value at risk, and about daily changes in portfolio value.

\section{Liquidity risk}

Quantitative information about liquidity risk was limited in the 1995 annual reports, as it was in the 1994 reports. The topic generally was addressed through discussion of overall institutional liquidity requirements and policies.

\section{Disclosures about End-User Derivatives}

The most common disclosure about end-user derivatives was general information about positions: notional amounts, maturities, and fair values (table 4). The most prevalent means of conveying information about how derivatives were used to manage a bank's interest rate risk continued to be a gap position schedule (table 6). ${ }^{10}$ All banks publishing a gap schedule cautioned that it represented only a point in time and did not capture option and other dynamic characteristics of the balance sheet. In several reports the gap schedule was supplemented either by a discussion of the effect of a hypothetical rate shock on capital or earnings or by a discussion of earnings-at-risk methods applied to nontrading portfolios. Publishing these alternatives to gap analysis was new in the 1994 reports and became more widespread in 1995. Most banks, in varying detail,

10. Gap analysis is a method used to estimate interest rate risk in which financial instruments are categorized by maturity in a series of time bands. Liabilities are subtracted from assets in each time interval, and the magnitude of the difference gives an indication of interest sensitivity. Banks can use derivatives to adjust their sensitivity to interest rate risk. 
described whether the derivatives were linked to specific components of the balance sheet or were used to manage overall, or macro, exposures. Reflecting the expansion of value-at-risk methods to activities not related to trading, one bank furnished quantitative information on the value at risk related to its nontrading portfolios.

As a result of minor changes in generally accepted accounting principles, the 1994 annual reports contained clearer, more understandable information about the fair value of the financial instruments in the firms' portfolios. Firms were required to disclose the fair value of financial assets and liabilities carried at historical cost separately from the fair value of derivatives used to hedge these instruments. This approach makes it much more obvious whether an instrument was favorable (that is, an asset from which the bank could expect to receive cash) or unfavorable (a liability on which the bank probably would pay cash), given year-end prices or interest rates. The 1995 reports showed little change in how this information was presented.

\section{Disclosures about Earnings}

For 1995, all ten banks disaggregated their trading revenues: Nine reported their results according to line of business or risk exposure with little differentiation between derivative and other instruments, and one reported about derivatives only (table 7). These numbers compare favorably with the 1994 reports,

7. Number of top ten banks disclosing data on income relating to derivatives in their annual reports, 1993-95

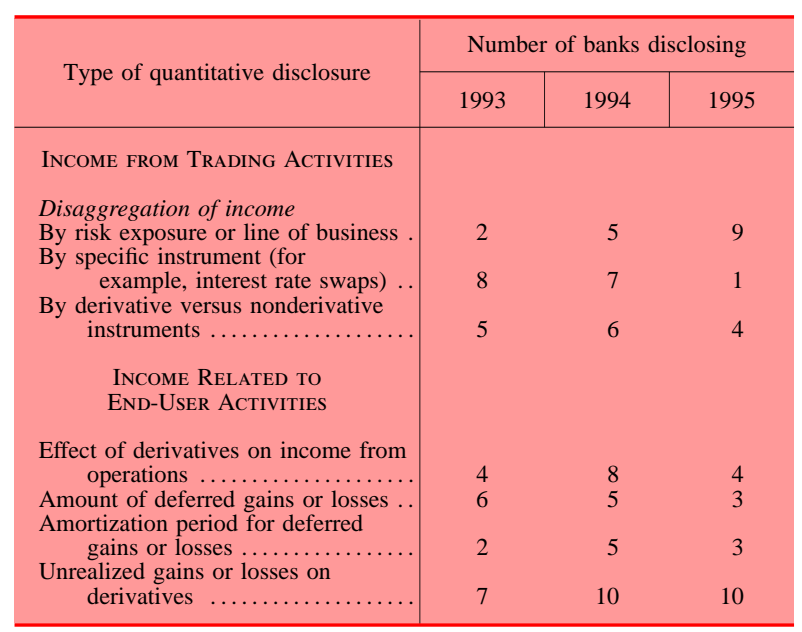

in which most banks gave only the minimum required information (that is, they reported only about derivatives). As a result, the 1995 reports gave a more complete picture of profits and risks from trading both derivative and nonderivative financial instruments.

In contrast, fewer banks gave details about the effects of end-user derivatives on accrual-basis accounting income and expense. Only four banks reported the effect on operating income of derivatives accounted for on an accrual basis, compared with eight in 1994. And only three banks disclosed gains or losses from end-user derivatives that had been deferred and provided details on when the deferrals would be reflected in future earnings, down from five in 1994. The absence of these details makes it somewhat more difficult to assess the accounting consequences of a bank's hedging activities (for example, whether income will decrease in future years when losses that had been deferred are recognized.)

\section{CONCLUSION}

The detail and clarity of information about derivatives and trading published by the top ten U.S. dealer banks continues to improve. The banks that had the more innovative annual reports in 1994 also led the group in 1995, reporting more quantitative details on value at risk and the results of their trading activities. Also as was the case in 1994, the disclosures of those banks whose trading revenues make up a larger share of their income tended to be more informative about derivatives and trading. Institutions with larger traditional banking segments devoted more attention to those lines of business than to trading.

The experimentation in better approaches to disclosure that has been encouraged by standards setters and others is evident in the variety of methods used to present information about derivatives activitiesand also in the discarding of some information that was provided in 1994. None of the reports can be singled out as the best; most of the banks had a novel approach to reporting on some aspect of their derivatives activities that was not used by the others. Disclosures about market risk have been greatly improved, but it appears to us that credit risk disclosures are lagging and need more depth. Further experimentation should be encouraged, as these private efforts have made significant strides in increasing the transparency of derivatives activities. 